\title{
Electrochemical advanced oxidation processes (EAOPs) as alternative treatment techniques for carwash wastewater reclamation
}

\author{
Soliu O. Ganiyu ${ }^{\text {a, }}$, Elisama Vieira dos Santos ${ }^{\mathrm{b}}$, Emily Cintia Tossi de Araújo Costa ${ }^{\mathrm{a}}$, \\ Carlos A. Martínez-Huitle a, c, ** \\ a Institute of Chemistry, Federal University of Rio Grande do Norte, Lagoa Nova, CEP 59078-970, Natal, RN, Brazil \\ ${ }^{\mathrm{b}}$ Science and TechnologySchool, Federal University of Rio Grande do Norte, Lagoa Nova, CEP 59078-970, Natal, RN, Brazil \\ ${ }^{\mathrm{c}}$ National Institute for Alternative Technologies of Detection, Toxicological Evaluation and Removal of Micropollutants and Radioactives (INCT-DATREM), \\ Institute of Chemistry, Unesp, P.O. Box 355, 14800-900 Araraquara, SP, Brazil
}

\section{H I G H L I G H T S}

- Complete removal of anionic surfactants and organic matter from carwash wastewater.

- Decay of anionic surfactants and COD follow the sequence: $\mathrm{EO}<\mathrm{EO}-\mathrm{H}_{2} \mathrm{O}_{2}<$ EF.

- Formation of short-chain carboxylic acids as the final organic product.

- Electrochemical techniques studied is an Efficient method for carwash wastewater treatment.

\section{A R T I C L E I N F O}

\section{Article history:}

Received 27 May 2018

Received in revised form

8 August 2018

Accepted 9 August 2018

Available online 11 August 2018

Handling Editor: E. Brillas

\section{Keywords:}

Electrochemical advanced oxidation

processes

Electrooxidation

Electro-Fenton

Carwash wastewater

Anionic surfactants

Organic matter

\begin{abstract}
A B S T R A C T
Electrochemical advanced oxidation processes such as electrooxidation (EO), electrooxidation with hydrogen peroxide generation $\left(\mathrm{EO}-\mathrm{H}_{2} \mathrm{O}_{2}\right)$ and electro-Fenton process (EF) have been investigated as alternative treatment techniques for complete removal of anionic surfactants and organic matters from real carwash wastewater. The electrochemical processes were performed with acidified real carwash wastewater using boron doped anode and carbon felt cathode. In all cases, the chemical oxygen demand (COD) removal efficiency was always increased with rise in applied current and complete organic matter decay was achieved at applied current of $500 \mathrm{~mA}$ or above after $6 \mathrm{~h}$ of electrolysis. Faster and higher COD decay was observed with EF compared to either $\mathrm{EO}$ or $\mathrm{EO}-\mathrm{H}_{2} \mathrm{O}_{2}$ treatment, at all currents and electrolysis time. Besides, complete degradation of anionic surfactants - the major organic content of the wastewater could be achieved at all applied currents studied irrespective of the process used, indicating the efficacy of processes for total remediation of real carwash wastewater. The short-chain carboxylic acids formed as the final organic byproducts were identified and quantified by ion-exclusion chromatography. More so, lower energy consumption and higher current efficiency were achieved with EF compared to EO- $\mathrm{H}_{2} \mathrm{O}_{2}$. Electrochemical treatment was found to be a powerful technology for the complete abatement of organic matter in carwash wastewater for possible reuse.
\end{abstract}

() 2018 Published by Elsevier Ltd.

\section{Introduction}

Electrochemical advanced oxidation processes (EAOPs) such as electrooxidation (EO) and electro-Fenton (EF) process have been

\footnotetext{
* Corresponding author.

** Corresponding author. Institute of Chemistry, Federal University of Rio Grande do Norte, Lagoa Nova, CEP 59078-970, Natal, RN, Brazil.

E-mail addresses: oladejosoliu@gmail.com (S.O. Ganiyu), carlosmh@quimica. ufrn.br (C.A. Martínez-Huitle).
}

widely studied for the remediation of persistent organic pollutants (POPs) from wastewater and soil (Brillas et al., 2009; Panizza and Cerisola, 2009; Rodrigo et al., 2014; Ganiyu et al., 2015; MartínezHuitle et al., 2015). These processes are highly efficient and versatile, requiring lowest amounts of chemicals or sometimes none, for producing oxidants, which make them safe and environmental friendly technologies. Oxidation of organics in EO and EF is mainly by hydroxyl radicals $(\cdot \mathrm{OH})$ mediation, which is the second strongest oxidant known after fluorine, with a standard reduction potential of $-2.8 \mathrm{~V}$ against SHE and can react non-selectively with organic 
molecules, leading to their oxidation until reaching a high mineralization degree (Martínez-Huitle and Ferro, 2006; Salazar et al., 2008; Oturan and Aaron, 2014; Oturan et al., 2017; MartínezHuitle and Panizza, 2018). The $\cdot \mathrm{OH}$ is electrochemically generated either directly by means of water oxidation at the surface of a suitable anode (EO) (Eq. (1)) or indirectly by total or partial in-situ production of Fenton's reagents $\left(\mathrm{Fe}^{2+}+\mathrm{H}_{2} \mathrm{O}_{2}\right)$ (Eq. (2)) (PeraltaHernández et al., 2006; Brillas et al., 2009; Panizza and Cerisola, 2009; Chaplin, 2014). With suitable cathode electrode (carbonaceous materials), $\mathrm{H}_{2} \mathrm{O}_{2}$ as a weak oxidant can be electrogenerated from two electron reduction of dissolved oxygen in EO (Eq. (3)), which has led to the so called EO- $\mathrm{H}_{2} \mathrm{O}_{2}$ (Fernades Rêgo et al., 2014; Oturan and Aaron, 2014; Ganiyu et al., 2016). Besides, the use of such cathode material in EF ensures that only catalytic quantities of $\mathrm{Fe}^{2+}$ are added to the wastewater because this species is continuously regenerated (Eq. (4)) at the cathode from the $\mathrm{Fe}^{3+}$ formed in Fenton's reaction (Eq. (2)) (Sirés and Brillas, 2012; Solano et al., 2015; Bañuelos et al., 2016; Lin et al., 2017; Ganiyu et al., 2018).

$\mathrm{M}_{(\mathrm{s})}+\mathrm{H}_{2} \mathrm{O} \rightarrow \mathrm{M}(\cdot \mathrm{OH})+\mathrm{H}^{+}+e^{-}$

$\mathrm{Fe}^{2+}+\mathrm{H}_{2} \mathrm{O}_{2}+\mathrm{H}^{+} \rightarrow \mathrm{Fe}^{3+}+\cdot \mathrm{OH}+\mathrm{H}_{2} \mathrm{O}$

$\mathrm{O}_{2}+2 \mathrm{H}^{+}+2 \mathrm{e}^{-} \rightarrow \mathrm{H}_{2} \mathrm{O}_{2}$

$\mathrm{Fe}^{3+}+\mathrm{e}^{-} \rightarrow \mathrm{Fe}^{2+}$

Among the anode materials currently in existence, boron doped diamond (BDD) thin film electrodes are the best anode materials known for electrochemical wastewater treatment because of its ability to generate large quantities of weakly adsorbed BDD $(\cdot \mathrm{OH})$. As a "non-active" anode, BDD can achieve complete destruction of organic pollutants (electrochemical combustion) (Panizza and Cerisola, 2009; Ruiz et al., 2011; Chaplin, 2014; Bañuelos et al., 2016; Morales et al., 2018). In contrast, when "active" anodes such as $\mathrm{Pt}, \mathrm{IrO}_{2}$ or $\mathrm{RuO}_{2}$ are used, the produced $\mathrm{M}(\cdot \mathrm{OH})$ are further oxidized to chemisorbed oxygen or superoxide species, which are weak oxidants that could only achieve degradation (electrochemical conversion) with rare mineralization of the organic pollutants (Cañizares et al., 2002; Cavalcanti et al., 2013; Sopaj et al., 2015; Durán et al., 2018). Additionally, BDD anodes has distinguished technological important properties such as inert surface with low adsorption properties, excellent corrosion and mechanical stability as well as extremely high $\mathrm{O}_{2}$-evolution overpotential, which enhance the reactivity of the organic at the anode surface (Panizza and Cerisola, 2009; Chaplin, 2014).

Nowadays, large volume of wastewater produced by carwash plants and clean-garages has been of serious concern from environmental protection and resources conservation/effective utilization point of view. Besides, the exponential growth in number of car washing plants/garages and in turn volume of water consumption due to increased number of vehicle owners, most carwash wastewater effluents are directly discharge into the environment/surface water bodies without prior treatment (Hamada and Miyazaki, 2004). Unfortunately, this wastewater contains many potential hazardous pollutants, such as detergents and surfactants, which can be poisonous to aquatic life, oil, grease, solvent-based solutions and chemicals, heavy metals from car paints and sometimes microplastics from wearing of the washing brush as well as tires of the vehicle (Paxéus, 1996). In most developed countries, the wastewater end up in municipal treatment plants, which in many cases employed conventional treatment techniques that are not efficient for complete removal of persistent organic pollutants (Sirés and Brillas, 2012). Recently, many European countries have enshrined legislation for water recycling in carwash workshops in order to reduce the volume of water consumed as well as pollutants released to the municipal treatment systems. For instance, Germany and Austria has imposed a recycling percentage higher than $80 \%$, whereas Netherlands and Scandinavian countries has legalized a maximum fresh water consumption of 60-70 L per car (Boussu et al., 2007; Panizza and Cerisola, 2010a). However, no restriction or regulations concerning carwash wastewater has been established in most developing countries like Brazil; as such the wastewater is released directly into the sewage system or surface water. Therefore, efficient approaches are needed to treat the wastewaters in order to remove the hazardous contents, and also for possible reuse of these effluents after treatment. Some treatment techniques such as electro/chemical coagulation (Rodriguez Boluarte et al., 2016; Gönder et al., 2017; Mohammadi et al., 2017), physicochemical processes (membrane filtration and flocculation-adsorption) (Hamada and Miyazaki, 2004; Al-Odwani et al., 2007; Boussu et al., 2007; Pinto et al., 2017), chemical oxidation (Bhatti et al., 2011) and electrooxidation (Panizza and Cerisola, 2010a, 2010b) have been applied for the reclamation of carwash wastewater but only combined electrocoagulation-electrooxidation treatment achieved complete COD removal as well as attaining greater reuse efficiency. However, no studies on comparing the performances of electrochemical treatments, in particular by using EF process, for reclamation of carwash effluent have been reported in literature. Some of the recent studies on reclamation of carwash wastewater are summarized in Table SM-1.

In this paper, the feasibility of applying EAOPs such as EO, EO$\mathrm{H}_{2} \mathrm{O}_{2}$ and $\mathrm{EF}$ techniques for carwash wastewater depollution has been investigated. The influence of the type of electrochemical technology was evaluated on the elimination of the organic matter and anionic surfactants contained in a real carwash effluent obtained from one of the largest auto-wash companies in Natal (Brazil). Besides, operation parameters such as applied current density and $\mathrm{Fe}^{2+}$ dosage and source were also studied to determine the reuse viability. The data obtained were used to estimate the current efficiency and energy consumption for each of the electrochemical treatments.

\section{Experimental}

\subsection{Chemicals}

The real carwash wastewater used in this study was obtained from central auto-wash company, Natal (Brazil). Sodium sulfate $\left(\mathrm{Na}_{2} \mathrm{SO}_{4}\right)$ used as supporting electrolyte during the electrolysis was supplied by Andriol chemical, Brazil. Iron II sulfate heptahydrate $\left(\mathrm{FeSO}_{4} \cdot 7 \mathrm{H}_{2} \mathrm{O}\right)$, a hydrous iron (III) oxide $\left(\mathrm{Fe}_{2} \mathrm{O}_{3}\right.$, iron (III) nitrate nonahydrate $\left(\mathrm{Fe}\left(\mathrm{NO}_{3}\right)_{3} \cdot 9 \mathrm{H}_{2} \mathrm{O}\right)$ and ammoniacal iron (II) sulfate $\left(\mathrm{NH}_{4} \mathrm{Fe}\left(\mathrm{SO}_{4}\right)_{2}\right.$ employed as iron source dosage were reagent grade obtained from Sigma Aldrich. Analytical grade of sulfuric acid and sodium hydroxide were obtained from Andriol chemical, Brazil. All solutions were prepared with ultra-pure water obtained from Millipore milli-Q water system with resistivity $>18 \mathrm{~m} \Omega \mathrm{cm}$ at room temperature.

\subsection{Electrolytic system}

Bulk electrolyses of the real wastewater were performed in small, open undivided cylindrical glass reactor of $6 \mathrm{~cm}$ diameter and $250 \mathrm{~mL}$ capacity with constant stirring by a magnetic bar to enhance mass transport towards the electrodes. The anode was $16 \mathrm{~cm}^{2}$ thin film BDD deposited on single crystal p-type Si substrate supplied by Adamant Technologies (Neuchatel, Switzerland) and 
synthesized by hot filament chemical vapor deposition technique (HF CVD) and a carbon-felt $(4 \mathrm{~cm} \times 4 \mathrm{~cm} \times 1.27 \mathrm{~cm})$ from Alfa Aesar was used as cathode. In all trials, the anode and the cathode were placed parallel to each other at the center of the reactor at approximately $2 \mathrm{~cm}$ inter-electrode distance. In the case of EO$\mathrm{H}_{2} \mathrm{O}_{2}$ and $\mathrm{EF}$ treatments, air was continuously bubbled at about $1 \mathrm{~mL} \mathrm{~min}^{-1}$ into the solution, starting from $10 \mathrm{~min}$ prior to electrolysis to maintain constant $\mathrm{O}_{2}$ concentration level in the solution. $\mathrm{H}_{2} \mathrm{O}_{2}$ was continuously electrogenerated from two electron reduction of dissolved $\mathrm{O}_{2}$ in the solution.

Real wastewater from carwash-company was filtered to removal solid particles prior to the electrolysis. Electrolysis were carried out with $230 \mathrm{~mL}$ of the wastewater containing $0.05 \mathrm{M} \mathrm{Na}_{2} \mathrm{SO}_{4}$ at $\mathrm{pH} 3$ and room temperature by applying a constant current ranging from 250 to $1500 \mathrm{~mA}$. In the EF trials, a predetermined amount of iron dosage was added to the real wastewater prior to electrolysis, in form of $\mathrm{FeSO}_{4} \cdot 7 \mathrm{H}_{2} \mathrm{O}, \mathrm{Fe}\left(\mathrm{NO}_{3}\right) \cdot 9 \mathrm{H}_{2} \mathrm{O}, \mathrm{Fe}_{2} \mathrm{O}_{3}$ or $\mathrm{NH}_{4} \mathrm{Fe}\left(\mathrm{SO}_{4}\right)_{2}$. The physicochemical properties of the as-received real carwash effluent are given in Table 1.

\subsection{Analytical procedures}

Electrolyses were performed under galvanostatic condition with constant current supplied by MIMIPA MPL-3305 M triple power DC generator. Solution $\mathrm{pH}$ and conductivity were measured with a $\mathrm{HI}$ $221 \mathrm{pH}$ meter and mCA 150 conductivimeter; both from HANNA Instrument (ROMANIA). The elimination of organic matter in the wastewater was assessed from the decay of the chemical oxygen demand (COD), which was measured using pre-dosage HANNA ${ }^{\circledR-}$ vials with $2 \mathrm{~mL}$ of sample. Samples were digested in a thermal reactor (HANNA instrument) at $200^{\circ} \mathrm{C}$ for $150 \mathrm{~min}$, cooled to room temperature and then, analyzed on spectrophotometer (Hanna HI table 83099). Three measurements were made and the average value with the standard deviation less than $2 \%$ was recorded. From the data obtained, the current efficiency (\% CE) and electric energy consumption per $\mathrm{g}$ COD removed $\left(\mathrm{E}_{\mathrm{c}}^{-1}(\mathrm{~g}\right.$ COD $)$ ) were estimated, according to Eqs. (5) and (6).

$$
\begin{aligned}
& \mathrm{CE}=\frac{\Delta C O D_{\text {exp }} F V_{s}}{8 I t} \times 100 \\
& \mathrm{E}_{\mathrm{c}_{(\mathrm{g} \mathrm{COD})^{-1}}}=\frac{E_{\text {cell }} I t}{(\Delta C O D)_{t} V_{s}}
\end{aligned}
$$

where $\triangle C O D_{\text {exp }}$ is the experimental COD decay, $F$ is the Faraday constant $\left(96487 \mathrm{C} \mathrm{mol}^{-1}\right), 8$ is the equivalent mass of oxygen ( $\mathrm{g}$ $\left.\mathrm{eq}^{-1}\right), V_{s}$ is the volume (L), $I$ is the current (A) and $t$ is time (s).

The decay of the anionic surfactants concentration, as the main organic constituent of the carwash wastewater, was determined during the electrochemical treatment by using a simplified spectrophotometric method based on the formation of ionic pair, anionic surfactant - methylene blue (AS-MB), following the procedure reported by Jurado et al. (2006). Briefly, $5 \mathrm{~mL}$ of electrolyzed sample was placed in a $10 \mathrm{~mL}$ glass test tube and alkalized by adding $200 \mu \mathrm{L}$ of $50 \mathrm{mM}$ sodium tetraborate solution at $\mathrm{pH} 10.5$. Two drops of phenolphthalein was added to change the color of the

Table 1

Characteristic of the as-received carwash wastewater.

\begin{tabular}{ll}
\hline Parameter & Value \\
\hline $\mathrm{COD}$ & $625 \pm 5 \mathrm{mg} \mathrm{L}^{-1}$ \\
$\mathrm{pH}$ & 7.31 \\
Anionic surfactants & $119.2 \pm 2.5 \mathrm{mg} \mathrm{L}^{-1}$ \\
conductivity & $125 \mu \mathrm{m} \mathrm{s}^{-1}$ \\
\hline
\end{tabular}

solution, followed by addition of $100 \mu \mathrm{L}$ of stabilized methylene blue ( $3.13 \mathrm{mM})$ and $4 \mathrm{~mL}$ of chloroform. The mixture was vigorously agitated for about $30 \mathrm{~s}$, and allowed to repose/settle in the test tube for $5 \mathrm{~min}$. The absorbance of the chloroform containing the AS-MB pair was measured without filtering at $650 \mathrm{~nm}$. The evolution of the short-chain carboxylic acids, as the final organic by-products of the degradation of organic matters, was followed by ultra-high performance liquid chromatography (u-HPLC - Dionex ultimate 3000) equipped with a L-2130 pump fitted with a C8 Acclaim OA, $4 \mathrm{~mm} \times 25 \mathrm{~cm}$ (i.d.) column at $40^{\circ} \mathrm{C}$, and coupled with a L-2400 UV detector selected at wavelength of $210 \mathrm{~nm}$, using $1 \% \mathrm{H}_{2} \mathrm{SO}_{4}$ as mobile phase at $0.2 \mathrm{~mL} \mathrm{~min}^{-1}$ flow rate.

\section{Results and discussion}

\subsection{Effect of iron quantity and source on COD decay during EF}

The effect of the quantity of iron $\left(0.2,0.5\right.$ and $\left.1 \mathrm{mM} \mathrm{Fe}^{2+}\right)$ and the nature of the iron source $\left(\mathrm{Fe}^{2+}, \mathrm{Fe}^{3+}\right.$ or solid $\left.\mathrm{Fe}^{\mathrm{III}}\right)$, as a function of COD decay, during EF treatment of the real carwash wastewater, is reported in Fig. 1. As depicted in Fig. 1a, even when no significant efficiency differences are observed between the iron amounts used, the optimum concentration of $\mathrm{Fe}^{2+}$ was found to be $0.5 \mathrm{mM}$, which favors the complete COD removal in $4 \mathrm{~h}$ of electrolysis. Meanwhile, a lower concentration of $0.2 \mathrm{mM} \mathrm{Fe}^{2+}$ showed inferior COD removal compared to $0.5 \mathrm{mM} \mathrm{Fe}{ }^{2+}$ at all electrolysis time during the $\mathrm{EF}$, indicating that not enough quantity of $\mathrm{Fe}^{2+}$ (limiting reagent) was used to promote the maximum catalytic decomposition of the large volume of electrogenerated $\mathrm{H}_{2} \mathrm{O}_{2}$ to $\cdot \mathrm{OH}$ by Fenton's reaction (Eq. (2)). Then, lower concentration of $\cdot \mathrm{OH}$ was generated by using $0.2 \mathrm{mM} \mathrm{Fe}^{2+}$, which resulted in a lower COD decay (96\% COD removal). Conversely, at higher $\mathrm{Fe}^{2+}$ concentration $(1 \mathrm{mM})$, slightly lower COD decay was observed compared to $0.5 \mathrm{mM} \mathrm{Fe}{ }^{2+}$, achieving approximately 98\% COD removal efficiency (inset panel of Fig. 1a) after $4 \mathrm{~h}$ of electrolysis. This behavior is related to the enhancement of the parasitic reaction between the $\mathrm{Fe}^{2+}$ ions and the generated $\cdot \mathrm{OH}$ (Eq. (7)) as well as the recombination of the $\cdot \mathrm{OH}$ (Eq. (8)), which consumed the oxidant without contributing to the organic matter decay (Brillas et al., 2009; Oturan and Aaron, 2014).

$$
\begin{aligned}
& \mathrm{Fe}^{2+}+\cdot \mathrm{OH} \rightarrow \mathrm{Fe}^{3+}+\mathrm{OH}^{-} \\
& 2 \cdot \mathrm{OH} \rightarrow \mathrm{H}_{2} \mathrm{O}_{2}
\end{aligned}
$$

Since $\cdot \mathrm{OH}$ is a non-selective oxidant, it reacts with dissolved organic matter in the wastewater as well as the excess $\mathrm{Fe}^{2+}$ ions present in the treated solution. This implies that, it is always imperative to optimize the quantity of iron used in order to achieve the maximum COD removal. The effect of the iron sources on the COD decay during the EF treatment of the carwash wastewater is shown in Fig. 1b. The efficiency of EF treatment catalyzed by two different soluble $\mathrm{Fe}^{3+}$ ions $\left(\mathrm{Fe}\left(\mathrm{NO}_{3}\right) \cdot 9 \mathrm{H}_{2} \mathrm{O}\right.$ and $\left.\mathrm{NH}_{4} \mathrm{Fe}\left(\mathrm{SO}_{4}\right)_{2}\right)$ and solid $\mathrm{Fe}_{2} \mathrm{O}_{3}$ sources for the removal of organic matters in the carwash wastewater was studied at constant concentration $(0.5 \mathrm{mM}$ for $\mathrm{Fe}\left(\mathrm{NO}_{3}\right) \cdot 9 \mathrm{H}_{2} \mathrm{O}$ and $\mathrm{NH}_{4} \mathrm{Fe}\left(\mathrm{SO}_{4}\right)_{2}$ and $0.25 \mathrm{mM}$ for $\mathrm{Fe}_{2} \mathrm{O}_{3}$ (equivalent of $0.5 \mathrm{mM}$ of $\mathrm{Fe}^{2+}$ in $\left.\mathrm{FeSO}_{4} \cdot 7 \mathrm{H}_{2} \mathrm{O}\right)$ ) under the same experimental conditions (i.e. pH 3 and $500 \mathrm{~mA}$ of applied current). As can be seen in Fig. 1b, similar COD decay was achieved by EF approach with the two soluble iron sources $\left(\mathrm{Fe}^{2+}\right.$ or $\left.\mathrm{Fe}^{3+}\right)$, which is relatively better than solid Fe ${ }^{\mathrm{III}}$ catalyzed process. The behavior achieved with soluble iron sources was expected because $\mathrm{Fe}^{2+}$ ions are easily and continuously regenerated at the large-surface area carbon-felt cathode (Eq. (4)). Indeed, previous studies have shown that the efficiency of $\mathrm{Fe}^{2+}$ and $\mathrm{Fe}^{3+}$ is almost the same when carbonaceous cathode materials such as carbon-felt and graphite 

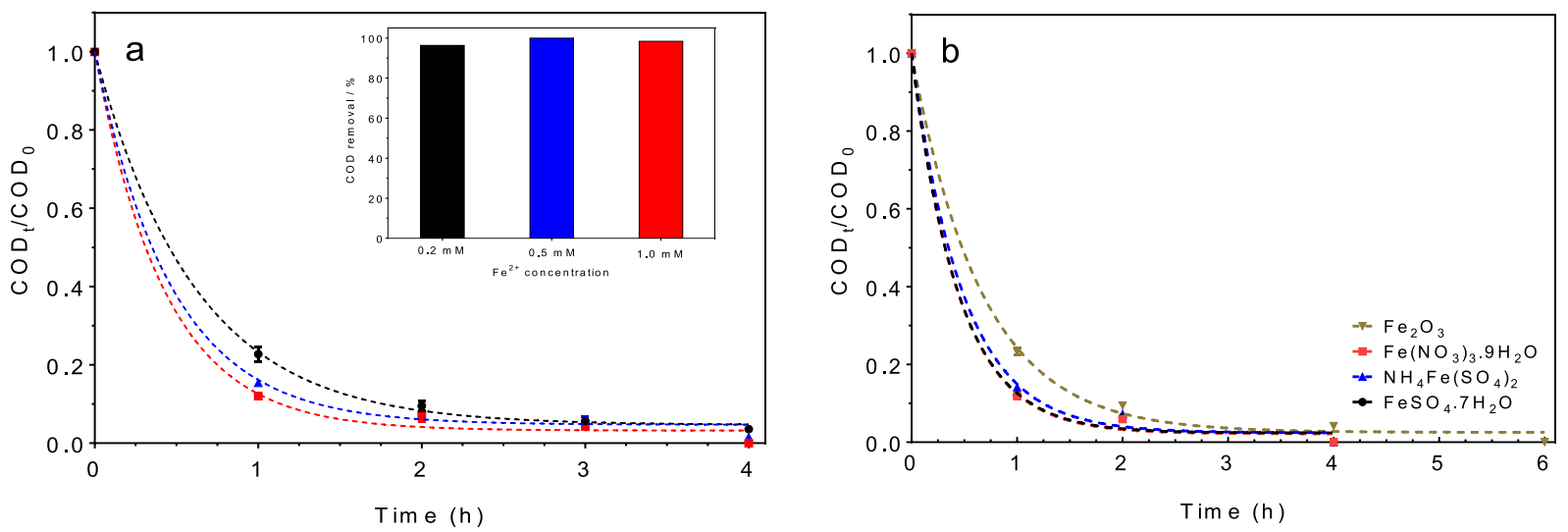

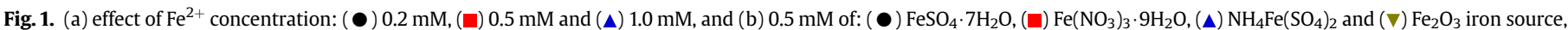
as a function of normalized COD decay vs electrolysis time during the treatment of real carwash wastewater by $\mathrm{EF}$ approach at $\mathrm{pH} 3$ and $500 \mathrm{~mA}$.

felt are used in EF treatment because almost all the $\mathrm{Fe}^{3+}$ ions are rapidly and completely reduced to $\mathrm{Fe}^{2+}$ (Qiang et al., 2003; Sirés et al., 2007; Brillas et al., 2009). Conversely, other cathode materials (carbon-PTFE GDEs) are inefficient for regenerating $\mathrm{Fe}^{2+}$ from $\mathrm{Fe}^{3+}$, which means that $\mathrm{Fe}^{2+}$ is the ideal catalyst for GDE electrodes to accelerate the production of $\cdot \mathrm{OH}$ at the early stages of the $\mathrm{EF}$ process (Brillas et al., 2004; Sirés et al., 2007). In the meantime, the use of solid $\mathrm{Fe}^{\mathrm{III}}$ as catalyst (i.e. $\mathrm{Fe}_{2} \mathrm{O}_{3}$ ) promoted a lower COD decay efficiency because $\mathrm{Fe}_{2} \mathrm{O}_{3}$ is slightly soluble at $\mathrm{pH} 3$, releasing a limited amount of $\mathrm{Fe}^{2+}$ ions in the solution to activate $\mathrm{H}_{2} \mathrm{O}_{2}$. Based
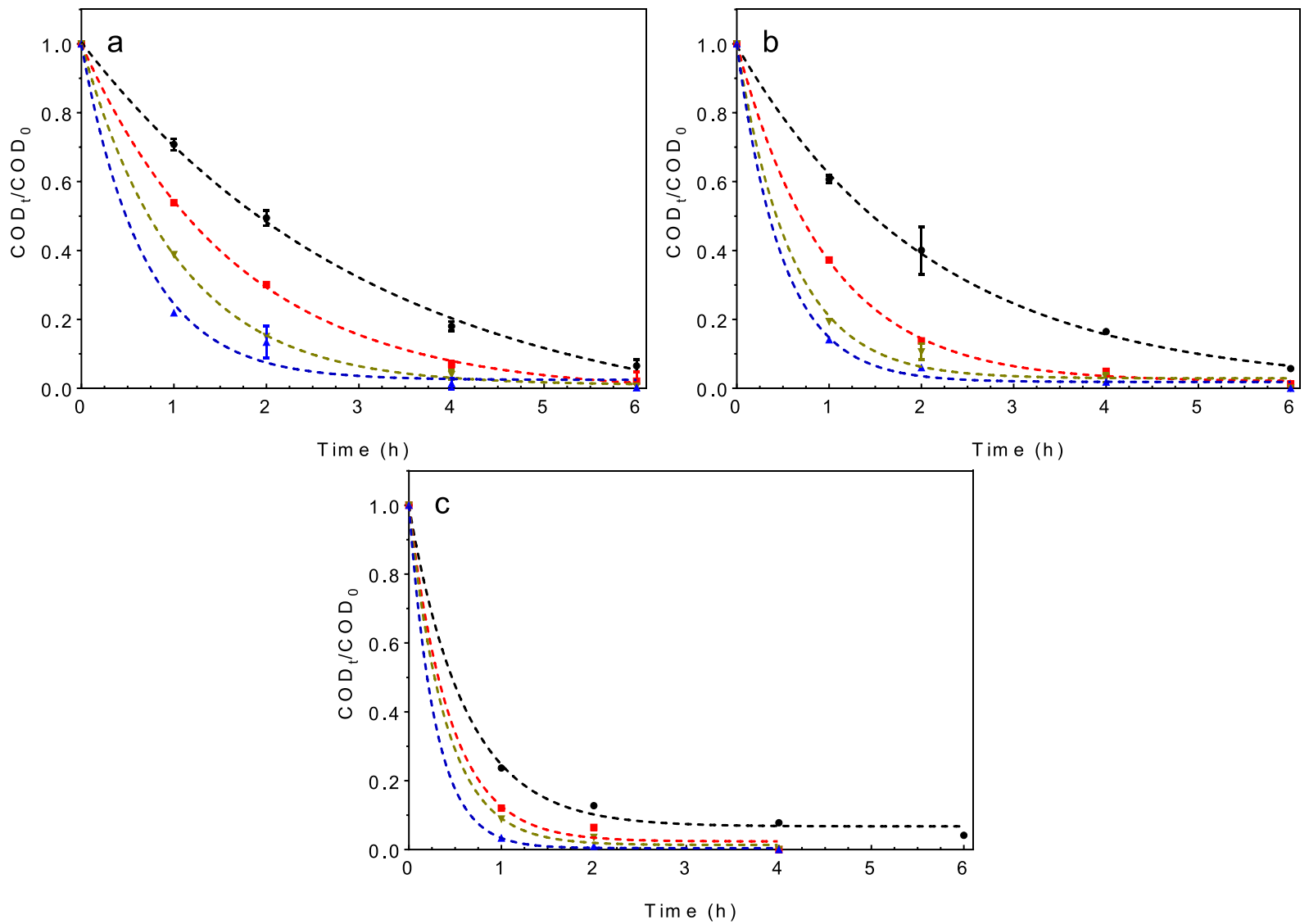

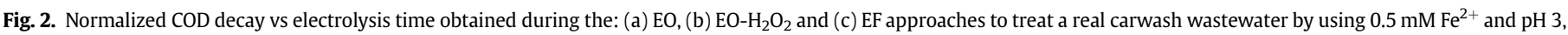

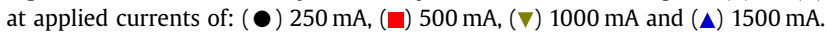

on the these results, further EF experiments reported in this work were performed by adding $0.5 \mathrm{mM} \mathrm{Fe}{ }^{2+}$ in form of $\mathrm{FeSO}_{4} \cdot 7 \mathrm{H}_{2} \mathrm{O}$.

\subsection{Comparative organic matter degradation by $\mathrm{EO}, \mathrm{EO}-\mathrm{H}_{2} \mathrm{O}_{2}$ and EF}

The decay of organic matter in the real carwash wastewater during its treatment by different EAOPs (i.e. EO, EO- $\mathrm{H}_{2} \mathrm{O}_{2}$ and $\mathrm{EF}$ ) by applying different currents (ranging from 250 to $1500 \mathrm{~mA}$ ) at $\mathrm{pH} 3$ is shown in Fig. 2. Faster and excellent COD decay was observed in
Tim e (h) 
all the EAOPs studied, mainly when a higher current was applied. For example, up to $96 \%$ of COD elimination was achieved at $250 \mathrm{~mA}$ after $6 \mathrm{~h}$ of electrolysis in all the EAOPs studied, whereas complete COD removal was observed at $500 \mathrm{~mA}$ or higher currents, at similar electrolysis time. This behavior is associated to the concomitant production of large quantities of $\operatorname{BDD}(\cdot \mathrm{OH})$ from water oxidation reaction at $\mathrm{BDD}$ surface $\left(\mathrm{EO}, \mathrm{EO}-\mathrm{H}_{2} \mathrm{O}_{2}\right.$ ) in parallel with the $\cdot \mathrm{OH}$ produced from Fenton's reaction (EF), as applied current increases (Martínez-Huitle et al., 2004, 2012; Urzúa et al., 2013; Ganiyu et al., 2017). It is worth noting that, in all cases the enhancement obtained when increasing applied current from 1000 to $1500 \mathrm{~mA}$ is not as significant as that produced when increasing from 500 to $1000 \mathrm{~mA}$, which in turn is less when compared to that achieved when raising the current from 250 to $500 \mathrm{~mA}$ (Fig. 2). This implies that at high applied current, the oxidation rate becomes mainly determined by the transport of substance (i.e. oxygen, iron ions and organic matters) towards the electrode and a reduction in the oxidation ability is attained due to consumption of the produced hydroxyl radicals in parasitic reactions that have limited contribution to the efficiency of the process (Sirés et al., 2010; Panizza et al., 2014). Moreover, the COD removal efficiency follows $\mathrm{EO}<\mathrm{EO}-\mathrm{H}_{2} \mathrm{O}_{2}<\mathrm{EF}$ sequence at all current studied because the dissolved organic matter is mineralized by both heterogeneous and homogeneous hydroxyl radicals $(\mathrm{BDD}(\cdot \mathrm{OH}) / \cdot \mathrm{OH})$ produced by EF process; whereas BDD $(\cdot \mathrm{OH})$ generated at the surface of the anode is the major oxidants in EO and $\mathrm{EO}-\mathrm{H}_{2} \mathrm{O}_{2}$. The $\cdot \mathrm{OH}$ produced in the bulk of the solution from Fenton's reaction (eq. (1)) by EF approach allow easier interaction with organic matter compared to the reaction attained with BDD $(\cdot \mathrm{OH})$, which are formed and confined to the anode region (GarciaSegura et al., 2016; Ganiyu et al., 2017).

The corresponding CE obtained for the trials of Fig. 2 is shown in Fig. 3. Similar profiles were obtained in all cases as a function of electrolysis time. The decrease in CE with rise in applied current is attributed to the enhancement on the parasitic reactions (recombination of the $\operatorname{BDD}(\cdot \mathrm{OH}) / \cdot \mathrm{OH}$ since they are produced in larger quantities), which consumed the generated hydroxyl radicals. Thus, the higher $\mathrm{CE}$ values obtained at lower current mean that the current was effectively employed to produce hydroxyl radicals, which judiciously oxidize the organic molecules (Sirés et al., 2010). Meanwhile, the exponential decrease of CE with electrolysis time implies a gradual loss in the oxidation ability of the electrolytic system due to the transport limitations as well as the formation of by-products such as short-chain aliphatic carboxylic acids which are less easily oxidized. Also, these conditions favor parallel wasting reactions like oxygen evolution (Eq. (9) and (10)) (Panizza et al., 2014; Oturan et al., 2017).

$$
\begin{aligned}
& 2 \mathrm{BDD}(\cdot \mathrm{OH}) \rightarrow 2 \mathrm{BDD}+\mathrm{H}_{2} \mathrm{O}_{2} \\
& 2 \mathrm{BDD}(\cdot \mathrm{OH}) \rightarrow 2 \mathrm{BDD}+\mathrm{O}_{(g)}+2 \mathrm{H}^{+}+2 \mathrm{e}^{-}
\end{aligned}
$$

Additionally, less than 100\% CE was obtained at all applied current studied regardless of the EAOPs applied (Fig. 3), which was due to the fact that hydroxyl radicals are not directly generated in the medium by the application of the current but requires the mass transport of the reactants, thus affecting the efficiency (Sirés et al.,
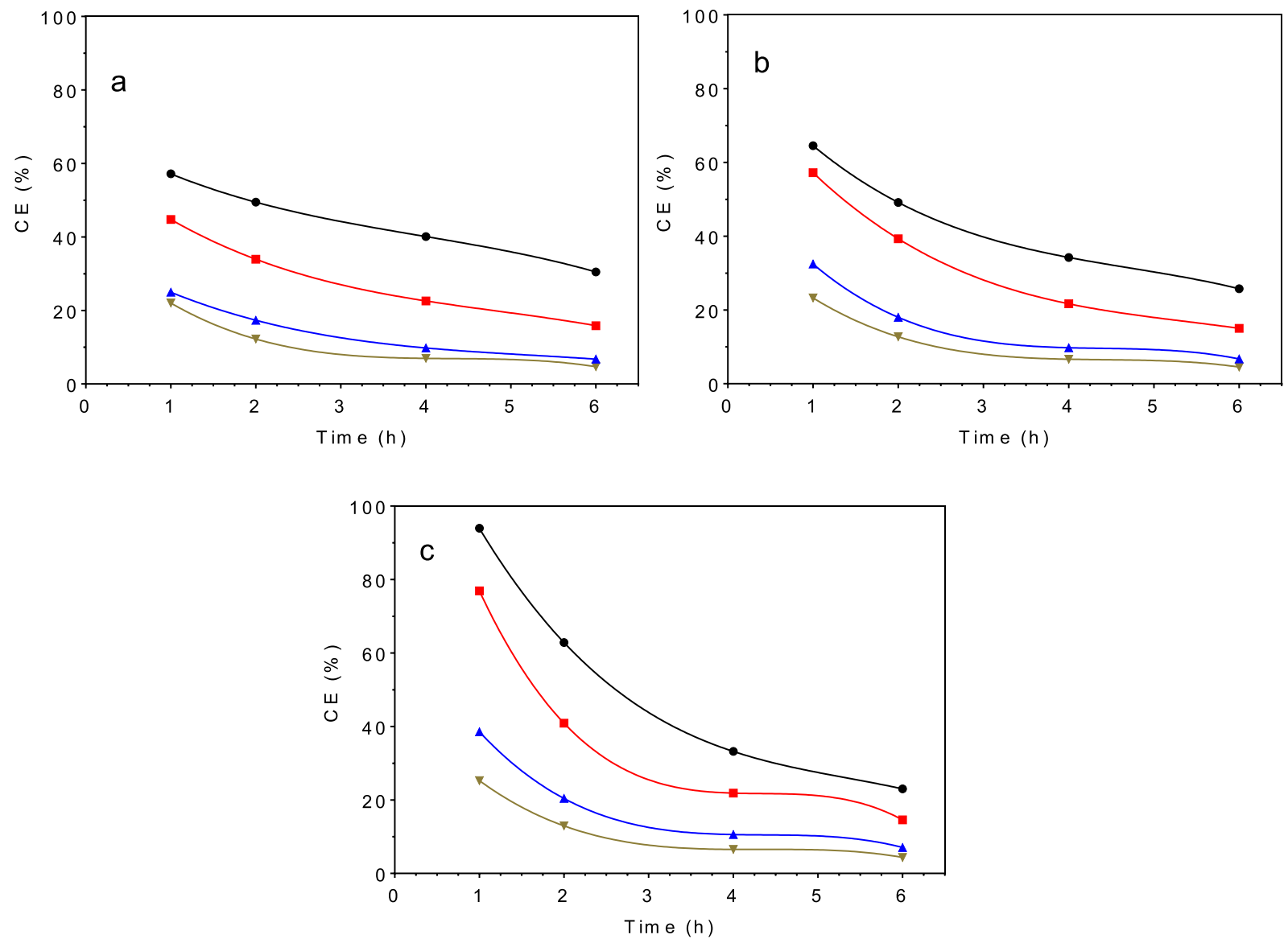

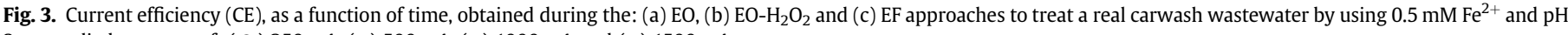
3, at applied currents of: ( $) 250 \mathrm{~mA},(\square) 500 \mathrm{~mA},(\boldsymbol{\nabla}) 1000 \mathrm{~mA}$ and (A) $1500 \mathrm{~mA}$. 
2010). The CE follows the sequence $\mathrm{EO}<\mathrm{EO}-\mathrm{H}_{2} \mathrm{O}_{2}<\mathrm{EF}$, at all currents and electrolysis time studies, which agrees with the higher oxidation efficiency of EF (Fig. 3c) compared to other processes. For instance, CE values of about $96 \%, 79 \%, 39 \%$ and $26 \%$ were achieved with EF by applying 250, 500, 1000 and $1500 \mathrm{~mA}$, respectively, while modest $\mathrm{CE}$ values were accomplished with $\mathrm{EO}-\mathrm{H}_{2} \mathrm{O}_{2}(65 \%$, $57 \%, 32 \%$ and $23 \%$ ) and EO (57\%, 45\%, 25\% and 22\%) approaches, under similar conditions.

\subsection{Energy consumption analysis}

The electrical energy consumption related to the COD removal during the treatment of the wastewater was estimated by using relationship in eq. (6) (Fig. 4). This parameter can constitute an interesting data in determining the economic feasibility and scaleup of the electrochemical treatment processes for industrial application. As shown in Fig. 4, the energy consumption per g COD removal increased with rise in applied current and electrolysis time as expected owing to the increase in the total charge supplied to the treated solution. For instance, electrical energy of 0.066, 0.142 , 0.441 and $0.792 \mathrm{kWh}$ were consumption per g COD after $6 \mathrm{~h}$ of treatment by EO process at 250, 500, 1000 and $1500 \mathrm{~mA}$ current respectively, while $0.069,0.195,0.489$ and $0.943 \mathrm{kWh}$ and 0.080 , $0.149,0.432$ and $0.769 \mathrm{kWh}$ of electrical energy were consumed, at similar applied current and treatment time for $\mathrm{EO}-\mathrm{H}_{2} \mathrm{O}_{2}$ and $\mathrm{EF}$ processes, respectively. In essence, quite similar energy consumption was observed in all the three electrochemical processes studied, which was expected since the same electrochemical cell (i.e. electrodes) was used throughout the treatment. Moreover, the
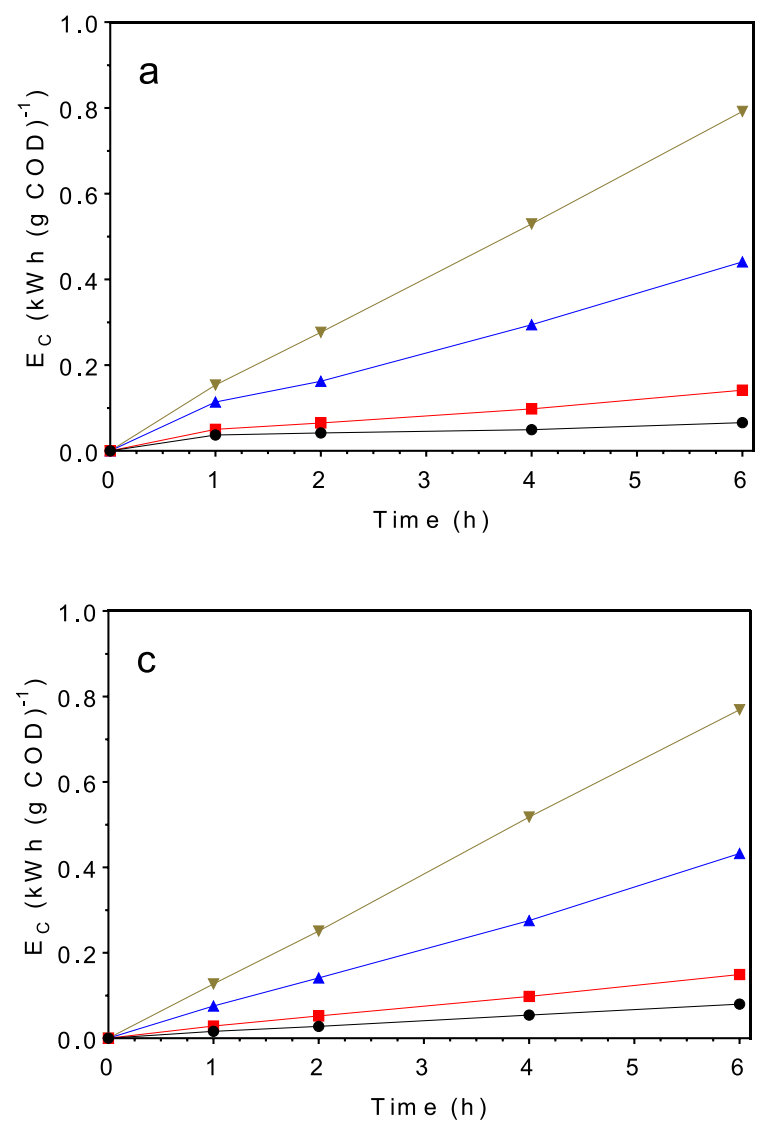

higher energy consumption at high applied current was slightly compensated by the excellent mineralization efficiency.

The energy cost per unit volume of the treated effluent at different applied current after $4 \mathrm{~h}$ of electrolysis is summarized in Table SM-2.

\subsection{Decay of anionic surfactant during the electrochemical treatment}

Anionic surfactants are the main constituent of most of commercial detergent and soaps used in auto-wash garages, and these are transfer into the wastewater during the washing process. The decay of the surfactant during the electrochemical treatment is shown in Fig. 5. As depicted in Fig. 5a, a significant degradation of the anionic surfactant was observed with increased current in EO. For instance, $83 \%$ and $96 \%$ of degradation efficiency were achieved after $4 \mathrm{~h}$ of electrolysis at 250 and $500 \mathrm{~mA}$, respectively; whereas a complete degradation of the surfactant was obtained after 2 and $1 \mathrm{~h}$ when $1000 \mathrm{~mA}$ and $1500 \mathrm{~mA}$ were applied, respectively, demonstrating the effectiveness of the process at higher currents. As explained in section 3.2, higher current promotes faster and large production of $\mathrm{BDD}(\cdot \mathrm{OH})$ in EO process, which can quickly oxidize the surfactant molecules in the solution (Panizza and Cerisola, 2010a, 2010b). At the same time, in some cases, surfactants can contribute with ionic species (e.g. release of sulfate ions from sodium dodecyl sulfate) that are electrochemically transformed in oxidants (Trellu et al., 2017; Araúijo et al., 2018). Comparative studies with $\mathrm{EO}-\mathrm{H}_{2} \mathrm{O}_{2}$ and $\mathrm{EF}$ at $500 \mathrm{~mA}$ (Fig. 4b) showed faster decay of the anionic surfactant concentration compared to EO. A

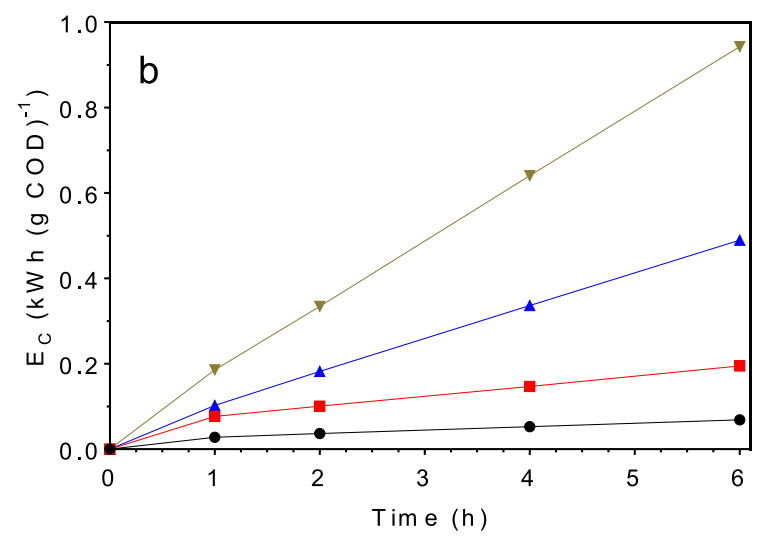

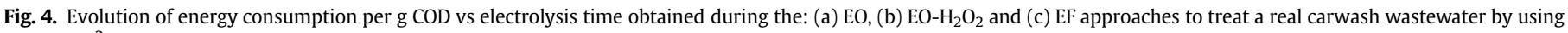

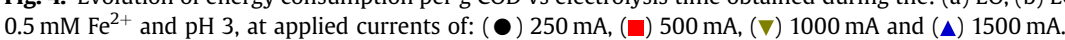


complete degradation of the anion surfactant in the solution was achieved within 4 and $2 \mathrm{~h}$ by EO- $\mathrm{H}_{2} \mathrm{O}_{2}$ and $\mathrm{EF}$, respectively, whereas EO degraded about $96 \%$ of the surfactant in $4 \mathrm{~h}$, under similar conditions. The enhanced surfactant decay rate in $\mathrm{EO}-\mathrm{H}_{2} \mathrm{O}_{2}$ compared to EO can be attributed to the production of $\mathrm{H}_{2} \mathrm{O}_{2}$ as a week oxidants, in addition to $\mathrm{BDD}(\cdot \mathrm{OH})$. The electrogenerated $\mathrm{H}_{2} \mathrm{O}_{2}$ can oxidize the surfactant (organic matter) either directly as week oxidant or indirectly as hydroperoxyl radicals $\left(\mathrm{HO}_{2}^{\circ}\right)$ formed from its reaction with produced $\operatorname{BDD}(\cdot \mathrm{OH})$, according to Eq. (11)) (Thiam et al., 2015; Ganiyu et al., 2016).

$\mathrm{H}_{2} \mathrm{O}_{2}+\mathrm{BDD}\left({ }^{\circ} \mathrm{OH}\right) \rightarrow \mathrm{BDD}\left(\mathrm{HO}_{2}{ }^{\circ}\right)+\mathrm{H}_{2} \mathrm{O}$

Previous studies (Ganiyu et al., 2016; Thiam et al., 2015) have demonstrated that electrogenerated $\mathrm{H}_{2} \mathrm{O}_{2}$ can significantly contribute to the degradation of easily oxidize organic pollutants, but rarely has impact on the mineralization efficiency due to its lower oxidation power and reactivity. Similarly, the higher decay rate of anionic surfactant observed during treatment with EF can be explained by the generation of large quantities of homogeneous $\cdot \mathrm{OH}$ in the bulk via Fenton's reaction (Eq. (2)), which can oxidize more rapidly the surfactants. It is important to indicate that, the elimination of the surfactant was also rapidly attained at 1000 and $1500 \mathrm{~mA}$ by EO- $\mathrm{H}_{2} \mathrm{O}_{2}$ and $\mathrm{EF}$ (Fig. $5 \mathrm{~b}$ and $5 \mathrm{c}$ respectively) in respect to EO approach. The characteristics of the final effluent after treatment at $500 \mathrm{~mA}$ using the three electrochemical processes are summarized in Table SM-3.

\subsection{Evolution of short-chain carboxylic acids}

The mineralization of organic pollutants in contaminated wastewater generally proceeds via formation of different cyclic organic intermediates, which are later degraded to short-chain aliphatic carboxylic acids as the final oxidation by-products of the process (Oturan et al., 2008; Garcia-Segura and Brillas, 2011). The presence of short-chain carboxylic acids in the treated solution were determined by ion-exclusion HPLC. The chromatograms of the electrolyzed solutions under the conditions of Fig. 2 at $500 \mathrm{~mA}$ clearly exhibited five well-defined peaks corresponding to oxalic, malonic, formic, glycoxylic and acetic acids at retention time $\left(t_{R}\right)$ of 8.4, 9.6, 12.2, 13.7, and 15.2 min respectively. These figures were confirmed by injecting standard solutions of these acids into ionexclusion reversed phase HPLC. As depicted in Fig. 6, the concentration profile of all generated acids follows accumulationdestruction cycles with high formation rate at the early stage of the treatment, thanks to the quick oxidation of the organic matter and its intermediates by the hydroxyl radicals. As showed in Fig. 6, carboxylic acids are accumulated more with EO (Fig. 6a) and EO$\mathrm{H}_{2} \mathrm{O}_{2}$ (Fig. 6b) treatments when compared to EF approach (Fig. 6c). In the latter case, a rapid decay of organic matter (in terms of COD) was achieved (Fig. 2), confirming the elimination of carboxylic acids. As expected, oxalic acid was the most accumulated in all cases because it is the final oxidation byproduct of both cyclic and non-cyclic compounds (Martínez-Huitle et al., 2005; Garcia-Segura and Brillas, 2011).
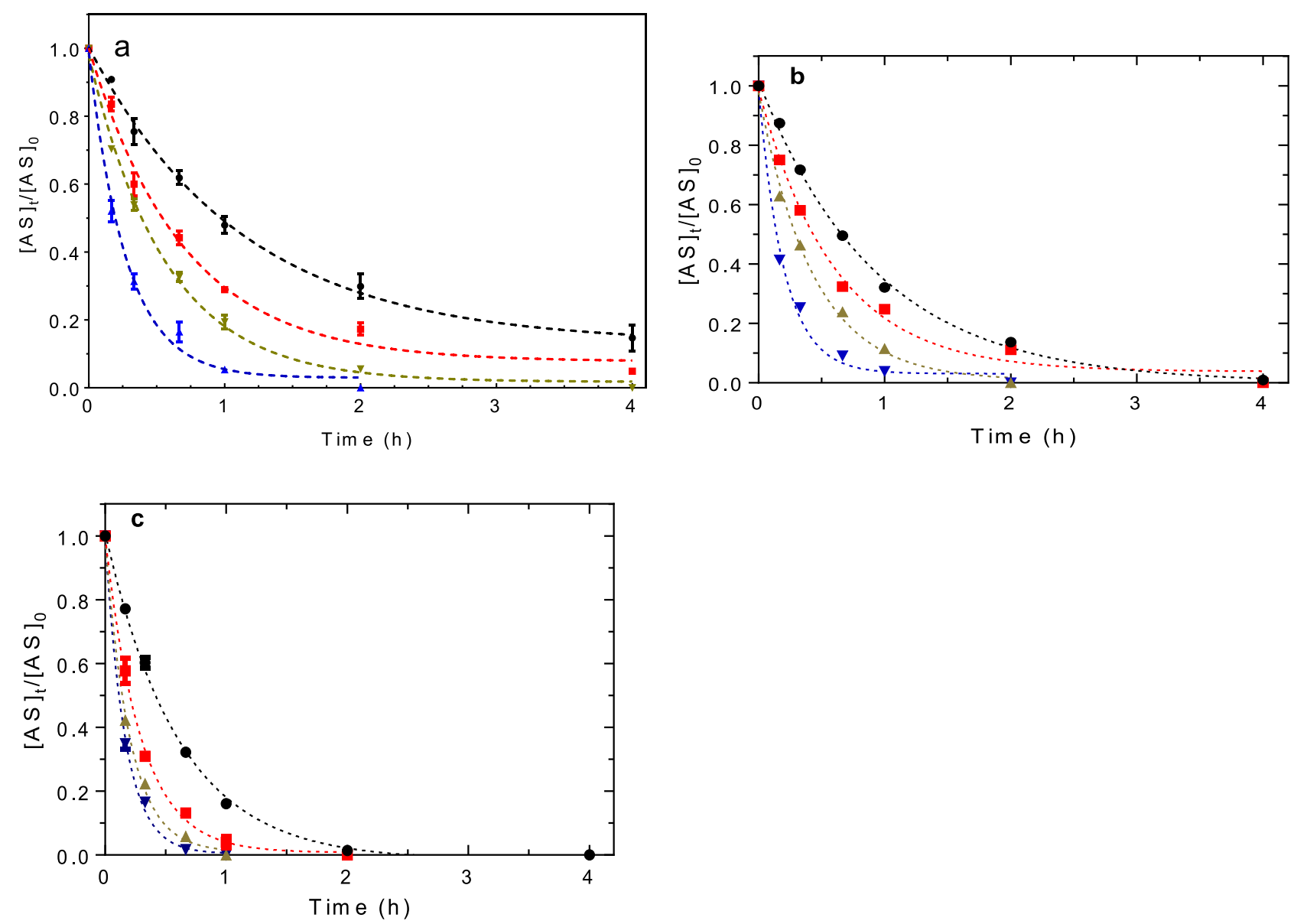

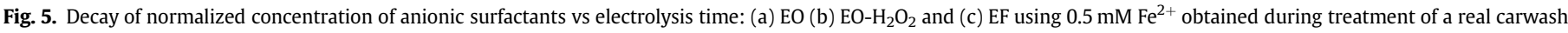
wastewater at applied current of ( $) 250 \mathrm{~mA},(\square) 500 \mathrm{~mA},(\boldsymbol{\nabla}) 1000 \mathrm{~mA}$ and $(\boldsymbol{\Delta}) 1500 \mathrm{~mA}$. 

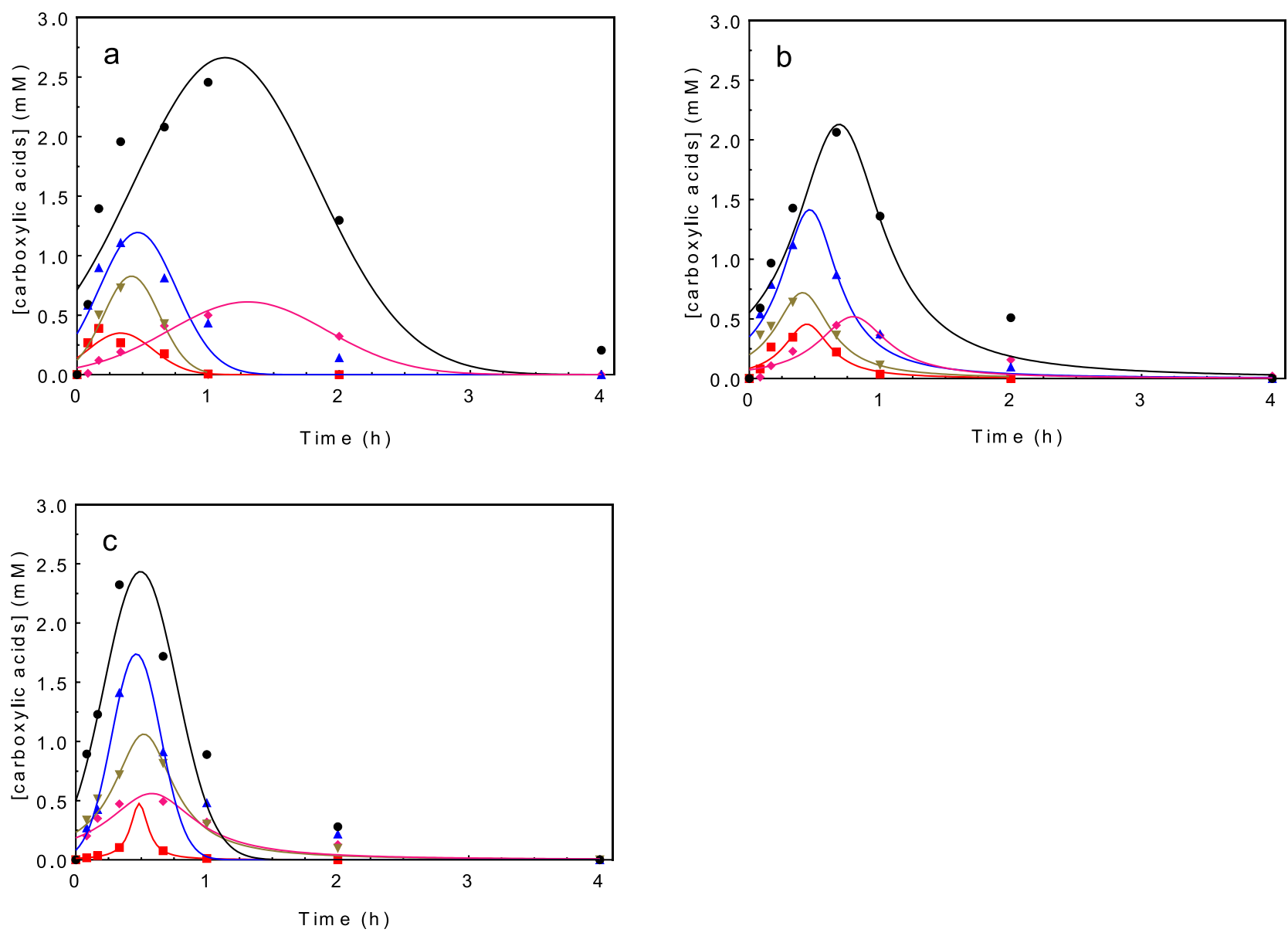

Fig. 6. Evolution of the concentration of carboxylic acids vs electrolysis time EF treatment of the real carwash wastewater at $500 \mathrm{~mA}$ and $\mathrm{pH} 3$.

\section{Conclusions}

The treatments of acidified real carwash wastewater by different electrochemical technologies, such as $\mathrm{EO}, \mathrm{EO}-\mathrm{H}_{2} \mathrm{O}_{2}$ and $\mathrm{EF}$, have been investigated. Complete degradation of the anionic surfactants and excellent removal of organic matter were observed, at all current studied, independent of the process used. An amount of $0.5 \mathrm{mM}$ of $\mathrm{Fe}^{2+}$ was found as optimum condition for EF process, which was independent of soluble iron source. Higher COD and surfactants removals as well as higher current efficiency and lower energy consumption were always achieved by EF compared to EO or EO- $\mathrm{H}_{2} \mathrm{O}_{2}$ approaches. Short-chain carboxylic acids, such as oxalic, malonic, formic, glycoxylic and acetic were identified, as the final oxidation intermediates in the treated solution, but these byproducts were also eliminated at the end of the treatments.

\section{Acknowledgement}

Financial support from National Council for Scientific and Technological Development (CNPq - 465571/2014-0; CNPq 446846/2014-7 and CNPq - 401519/2014-7) and Fundação de Amparo à Pesquisa do Estado de São Paulo (FAPESP 2014/50945-4) are gratefully acknowledged. Soliu O. Ganiyu gratefully acknowledges CAPES for the financial support under PNPD post-doctoral grant awarded.

\section{Appendix A. Supplementary data}

Supplementary data related to this article can be found at https://doi.org/10.1016/j.chemosphere.2018.08.044.

\section{References}

Al-Odwani, A., Ahmed, M., Bou-Hamad, S., 2007. Carwash water reclamation in Kuwait. Desalination 206, 17-28.

Araújo, K.C., Barreto, J.P., Cardozo, J.C., dos Santos, E.V., Araújo, D.M., MartínezHuitle, C.A., 2018. Sulfate pollution: evidence for electrochemical production of persulfate by oxidizing sulfate released by the surfactant sodium dodecyl sulfate. Environ. Chem. Lett. 1-6.

Bañuelos, J.A., García-Rodríguez, O., El-Ghenymy, A., Rodríguez-Valadez, F.J., Godínez, L.A., Brillas, E., 2016. Advanced oxidation treatment of malachite green dye using a low cost carbon-felt air-diffusion cathode. J. Environ. Chem. Eng. 4, 2066-2075.

Bhatti, Z.A., Mahmood, Q., Raja, I.A., Malik, A.H., Khan, M.S., Wu, D., 2011. Chemical oxidation of carwash industry wastewater as an effort to decrease water pollution. Phys. Chem. Earth ABC Sci. 36, 465-469. Technology and Policy for Water Pollution Control at the Watershed Scale: Current Issues and Future Challenges.

Boussu, K., Kindts, C., Vandecasteele, C., Van der Bruggen, B., 2007. Applicability of nanofiltration in the carwash industry. Separ. Purif. Technol. 54, 139-146.

Brillas, E., Baños, M.A., Camps, S., Arias, C., Cabot, P.-L., Garrido, J.A., Rodríguez, R.M., 2004. Catalytic effect of $\mathrm{Fe}^{2+} \mathrm{Cu}^{2+}$ and UVA light on the electrochemical degradation of nitrobenzene using an oxygen-diffusion cathode. New J. Chem. $28,314-322$.

Brillas, E., Sires, I., Oturan, M.A., 2009. Electro-Fenton process and related electrochemical technologies based on Fenton's reaction chemistry. Chem. Rev. 109, 6570-6631.

Cañizares, P., Martınez, F., Dıaz, M., Garcıa-Gómez, J., Rodrigo, M.A., 2002 
Electrochemical oxidation of aqueous phenol wastes using active and nonactive electrodes. J. Electrochem. Soc. 149, D118-D124.

Cavalcanti, E.B., Garcia-Segura, S., Centellas, F., Brillas, E., 2013. Electrochemical incineration of omeprazole in neutral aqueous medium using a platinum or boron-doped diamond anode: degradation kinetics and oxidation products. Water Res. 47, 1803-1815.

Chaplin, B.P., 2014. Critical review of electrochemical advanced oxidation processes for water treatment applications. Environ. Sci. Process. Impacts 16, 1182-1203.

Durán, F.E., de Araújo, D.M., do Nascimento Brito, C., dos Santos, E.V., Ganiyu, S.O. Martínez-Huitle, C.A., 2018. Electrochemical technology for the treatment of real washing machine effluent at pre-pilot plant scale by using active and nonactive anodes. J. Electroanal. Chem. 818, 216-222.

Fernades Rêgo, F.E., Sales Solano, A.M., da Costa Soares, I.C., da Silva, D.R., MartínezHuitle, C.A., Panizza, M., 2014. Application of electro-Fenton process as alternative for degradation of Novacron Blue dye. J. Environ. Chem. Eng. 2, 875-880.

Ganiyu, S.O., Oturan, N., Raffy, S., Cretin, M., Esmilaire, R., van Hullebusch, E., Esposito, G., Oturan, M.A., 2016. Sub-stoichiometric titanium oxide $\left(\mathrm{Ti}_{4} \mathrm{O}_{7}\right)$ as a suitable ceramic anode for electrooxidation of organic pollutants: a case study of kinetics, mineralization and toxicity assessment of amoxicillin. Water Res. 106, 171-182.

Ganiyu, S.O., Oturan, N., Raffy, S., Esposito, G., van Hullebusch, E.D., Cretin, M., Oturan, M.A., 2017. Use of sub-stoichiometric titanium oxide as a ceramic electrode in anodic oxidation and electro-Fenton degradation of the betablocker propranolol: degradation kinetics and mineralization pathway. Electrochim. Acta 242, 344-354.

Ganiyu, S.O., van Hullebusch, E.D., Cretin, M., Esposito, G., Oturan, M.A., 2015. Coupling of membrane filtration and advanced oxidation processes for removal of pharmaceutical residues: a critical review. Separ. Purif. Technol. 156, $891-914$.

Ganiyu, S.O., Zhou, M., Martínez-Huitle, C.A., 2018. Heterogeneous electro-Fenton and photoelectro-Fenton processes: a critical review of fundamental principles and application for water/wastewater treatment. Appl. Catal. B Environ. 235, 103-129.

Garcia-Segura, S., Brillas, E., 2011. Mineralization of the recalcitrant oxalic and oxamic acids by electrochemical advanced oxidation processes using a borondoped diamond anode. Water Res. 45, 2975-2984.

Garcia-Segura, S., Lima, A.S., Cavalcanti, E.B., Brillas, E., 2016. Anodic oxidation, electro-Fenton and photoelectro-Fenton degradations of pyridinium- and imidazolium-based ionic liquids in waters using a BDD/air-diffusion cell. Electrochim. Acta 198, 268-279.

Gönder, Z.B., Balcıoğlu, G., Vergili, I., Kaya, Y., 2017. Electrochemical treatment of carwash wastewater using Fe and Al electrode: techno-economic analysis and sludge characterization. J. Environ. Manag. 200, 380-390.

Hamada, T., Miyazaki, Y., 2004. Reuse of carwash water with a cellulose acetate ultrafiltration membrane aided by flocculation and activated carbon treatments. Desalination 169, 257-267.

Jurado, E., Fernández-Serrano, M., Núñez-Olea, J., Luzón, G., Lechuga, M., 2006. Simplified spectrophotometric method using methylene blue for determining anionic surfactants: applications to the study of primary biodegradation in aerobic screening tests. Chemosphere 65, 278-285.

Lin, H., Oturan, N., Wu, J., Sharma, V.K., Zhang, H., Oturan, M.A., 2017. Removal of artificial sweetener aspartame from aqueous media by electrochemical advanced oxidation processes. Chemosphere 167, 220-227.

Martínez-Huitle, C.A., dos Santos, E.V., de Araújo, D.M., Panizza, M., 2012. Applicability of diamond electrode/anode to the electrochemical treatment of a real textile effluent. J. Electroanal. Chem. 674, 103-107.

Martínez-Huitle, C.A., Ferro, S., De Battisti, A., 2005. Electrochemical incineration of oxalic acid: reactivity and engineering parameters. J. Appl. Electrochem. 35, 1087-1093.

Martínez-Huitle, C.A., Quiroz, M.A., Comninellis, C., Ferro, S., Battisti, A.D., 2004. Electrochemical incineration of chloranilic acid using $\mathrm{Ti} / \mathrm{IrO}_{2}, \mathrm{~Pb} / \mathrm{PbO}_{2}$ and $\mathrm{Si} /$ BDD electrodes. Electrochim. Acta 50, 949-956.

Martínez-Huitle, C.A., Rodrigo, M.A., Sirés, I., Scialdone, O., 2015. Single and coupled electrochemical processes and reactors for the abatement of organic water pollutants: a critical review. Chem. Rev. 115, 13362-13407.

Martínez-Huitle, C.A., Ferro, S., 2006. Electrochemical oxidation of organic pollutants for the wastewater treatment: direct and indirect processes. Chem. Soc. Rev. 35, 1324-1340.

Martínez-Huitle, C.A., Panizza, M., 2018. Electrochemical oxidation of organic pollutants for wastewater treatment. Curr. Opin. Electrochem. https://doi.org/ 10.1016/j.coelec.2018.07.010.

Mohammadi, M.J., Takdastan, A., Jorfi, S., Neisi, A., Farhadi, M., Yari, A.R., Dobaradaran, S., Khaniabadi, Y.O., 2017. Electrocoagulation process to Chemical and Biological Oxygen Demand treatment from carwash grey water in Ahvaz megacity, Iran. Data Brief 11, 634-639.

Morales, U., Escudero, C.J., Rivero, M.J., Ortiz, I., Rocha, J.M., Peralta-Hernández, J.M., 2018. Coupling of the electrochemical oxidation (EO-BDD)/photocatalysis $\left(\mathrm{TiO}_{2}-\right.$ $\mathrm{Fe}-\mathrm{N}$ ) processes for degradation of acid blue. BR dye. J. Electroanal. Chem. 808, 180-188.
Oturan, M.A., Aaron, J.J., 2014. Advanced oxidation processes in water/wastewater treatment: principles and applications. A review. Crit. Rev. Environ. Sci. Technol. 44, 2577-2641.

Oturan, M.A., Pimentel, M., Oturan, N., Sirés, I., 2008. Reaction sequence for the mineralization of the short-chain carboxylic acids usually formed upon cleavage of aromatics during electrochemical Fenton treatment. Electrochim. Acta $54,173-182$

Oturan, N., Ganiyu, S.O., Raffy, S., Oturan, M.A., 2017. Sub-stoichiometric titanium oxide as a new anode material for electro-Fenton process: application to electrocatalytic destruction of antibiotic amoxicillin. Appl. Catal. B Environ. 217, $214-223$.

Panizza, M., Cerisola, G., 2010a. Applicability of electrochemical methods to carwash wastewaters for reuse. Part 2: electrocoagulation and anodic oxidation integrated process. J. Electroanal. Chem. 638, 236-240.

Panizza, M., Cerisola, G., 2010b. Applicability of electrochemical methods to carwash wastewaters for reuse. Part 1: anodic oxidation with diamond and lead dioxide anodes. J. Electroanal. Chem. 638, 28-32.

Panizza, M., Cerisola, G., 2009. Direct and mediated anodic oxidation of organic pollutants. Chem. Rev. 109, 6541-6569.

Panizza, M., Dirany, A., Sirés, I., Haidar, M., Oturan, N., Oturan, M.A., 2014. Complete mineralization of the antibiotic amoxicillin by electro-Fenton with a BDD anode. J. Appl. Electrochem. 44, 1327-1335.

Paxéus, N., 1996. Vehicle washing as a source of organic pollutants in municipal wastewater. Water Sci. Technol. 33, 1-8. Hazard Assessment and Control of Environmental Contaminants in Water.

Peralta-Hernández, J.M., Meas-Vong, Y., Rodríguez, F.J., Chapman, T.W., Maldonado, M.I., Godínez, L.A., 2006. In situ electrochemical and photoelectrochemical generation of the fenton reagent: a potentially important new water treatment technology. Water Res. 40, 1754-1762.

Pinto, A.C.S., de Barros Grossi, L., de Melo, R.A.C., de Assis, T.M., Ribeiro, V.M. Amaral, M.C.S., de Souza Figueiredo, K.C., 2017. Carwash wastewater treatment by micro and ultrafiltration membranes: effects of geometry, pore size, pressure difference and feed flow rate in transport properties. J. Water Process Eng. 17, $143-148$.

Qiang, Z., Chang, J.-H., Huang, C.-P., 2003. Electrochemical regeneration of $\mathrm{Fe}^{2+}$ in Fenton oxidation processes. Water Res. 37, 1308-1319.

Rodrigo, M.A., Oturan, N., Oturan, M.A., 2014. Electrochemically assisted remediation of pesticides in soils and water: a review. Chem. Rev. 114, 8720-8745.

Rodriguez Boluarte, I.A., Andersen, M., Pramanik, B.K., Chang, C.-Y., Bagshaw, S. Farago, L., Jegatheesan, V., Shu, L., 2016. Reuse of car wash wastewater by chemical coagulation and membrane bioreactor treatment processes. Int. Biodeterior. Biodegrad. 113, 44-48. Challenges in Environmental Science and Engieering - 2015 .

Ruiz, E.J., Arias, C., Brillas, E., Hernádez-Ramírez, A., Peralta-Hernández, J.M., 2011 Mineralization of Acid Yellow 36 azo dye by electro-Fenton and solar photoelectro-Fenton processes with a boron-doped diamond anode. Chemosphere 82, 495-501.

Salazar, R., Navarrete-Encina, P.A., Camargo, C., Squella, J.A., Núñez-Vergara, L.J. 2008. Electrochemical oxidation of C4-vanillin- and C4-isovanillin-1,4-dihydropyridines in aprotic medium: reactivity towards free radicals. J. Electroanal. Chem. 622, 29-36.

Sirés, I., Brillas, E., 2012. Remediation of water pollution caused by pharmaceutical residues based on electrochemical separation and degradation technologies: a review. Environ. Int. 40, 212-229.

Sirés, I., Garrido, J.A., Rodríguez, R.M., Brillas, E., Oturan, N., Oturan, M.A., 2007. Catalytic behavior of the $\mathrm{Fe}^{3+} / \mathrm{Fe}^{2+}$ system in the electro-Fenton degradation of the antimicrobial chlorophene. Appl. Catal. B Environ. 72, 382-394.

Sirés, I., Oturan, N., Oturan, M.A., 2010. Electrochemical degradation of $\beta$-blockers. Studies on single and multicomponent synthetic aqueous solutions. Water Res. 44, 3109-3120.

Solano, A.M.S., Garcia-Segura, S., Martínez-Huitle, C.A., Brillas, E., 2015. Degradation of acidic aqueous solutions of the diazo dye Congo Red by photo-assisted electrochemical processes based on Fenton's reaction chemistry. Appl. Catal. B Environ. 168-169, 559-571.

Sopaj, F., Rodrigo, M.A., Oturan, N., Podvorica, F.I., Pinson, J., Oturan, M.A., 2015. Influence of the anode materials on the electrochemical oxidation efficiency. Application to oxidative degradation of the pharmaceutical amoxicillin. Chem. Eng. J. 262, 286-294.

Thiam, A., Brillas, E., Centellas, F. Cabot, P.L., Sirés, I., 2015. Electrochemical reactivity of Ponceau 4R (food additive E124) in different electrolytes and batch cells. Electrochim. Acta 173, 523-533.

Trellu, C., Oturan, N., Pechaud, Y., van Hullebusch, E.D., Esposito, G., Oturan, M.A. 2017. Anodic oxidation of surfactants and organic compounds entrapped in micelles - selective degradation mechanisms and soil washing solution reuse. Water Res. 118, 1-11.

Urzúa, J., González-Vargas, C., Sepúlveda, F., Ureta-Zañartu, M.S., Salazar, R., 2013. Degradation of conazole fungicides in water by electrochemical oxidation. Chemosphere 93, 2774-2781. 